\title{
Teaching English for the First Time: Frightening or Challenging?
}

\author{
Fika Megawati \\ English Education Study Program, \\ Universitas Muhammadiyah Sidoarjo, Indonesia \\ Yuli Astutik \\ English Education Study Program, \\ Universitas Muhammadiyah Sidoarjo, Indonesia
}

\begin{abstract}
To enhance the quality of teacher performance, teaching practicum is required by the Teacher Training and Education Faculty at university level as the pivotal compulsory course. The practicum is expected to give positive unforgettable experience for shaping their prior knowledge with contextual activities in the real school. This memory affects their next teaching journey according to the people they have met and interacted with during the program. Considering the significance of understanding the students' experience in performing their planned lesson inside the class, this study aims to describe the students' ideas during the Teaching Practicum Program, especially the effect of Teaching Media and Micro Teaching courses. Qualitative design was applied to investigate the students' responses through the questionnaire and document analysis. The result indicates that teaching practicum seems to take the students in a very new direction, and it needs significant effort for adaptation to maintain better communication with the internal school stakeholders, particularly school based mentors and students. Further, media use for English instruction provides benefits for the experience. This study implied that identifying teaching experiences leads to comprehend possible challenges to achieve success.
\end{abstract}

Keywords: practicum; method; media; pre-service teacher.

\section{Introduction}

Teaching needs passion. To be a teacher, someone's strong will is required (Pavić, 2014). If a teacher does not have high motivation when he or she delivers the materials in front of pupils, the learning atmosphere can be monotonous and less interactive (Agustiani, 2016). Not everyone is interested in selecting the profession of a teacher although they consider themselves knowledgeable or competent. In addition, this case can be influenced by low ability to fulfil 
teaching competence set by the Indonesian Minister of National Education Regulation No.16/2007, namely personality, pedagogy, professionalism, and social abilities. In other words, teaching is a complex process. Thus, developing the English skills during CPD (or teacher training) can be. When we prepare English pre-service teacher to face practicum in the real school, candidate teacher educators are expected to work hard to shape their meaningful background knowledge with plenty of experiences (Goodwin \& Kosnik, 2013).

Considering the importance of developing the competence of teachers in teaching practice, investigating the process language instruction inside the classroom become the way to reflect the quality of the student teachers. All language knowledge they obtained from the campus courses is to be delivered with some modification according to the situation. Trial and error is common to find, and the most effective strategy in managing classroom with diversities, including linguistic background (Curran, 2003). Different linguistic background may result various students' engagement during the class.

Problems and difficulties are part of achieving a successful experience. The common problems appear related to supervisor, mentor, and student (Riesky, 2013). Those three parties always follow the student teacher activities and responsibilities. Students in the class do not completely obey what the preservice teachers say or instruct. The diverse characteristics of school students can encourage prospective teachers to be creative and provide innovative learning experiences/activities. It takes several days to read or recognize the characters as well as their attention. In teaching, a sense of attracting and entertaining is also required. This can be learnt in the pre-requisite subjects provided by program study. Two of them are Teaching Media and Micro Teaching. In some universities, micro teaching is inserted in teaching practicum, called teaching practicum I.

The subject 'teaching media' may have several names in universities. Although referred to various names, the content is almost similar, namely training the preservice teachers' skill in designing, creating, and applying the instructional media to the target learners in their future career. Responding the industrial revolution 4.0, the capacity of the teacher educators needs to be enhanced. Everything is empowered to be smart through technology, including transferring science to the pupils. Thus, inserting virtual concept to media, materials as well as teaching method is not something new in today's education (Adnan, 2007; Ko, 2017). Browsing the internet for obtaining a lot of information is what our learners do in their life. As a result, no time and no excuse for not being updated with technology for today's language instruction. This is what we call technologically competent (Selwyn \& Husen, 2010).

The old issue of teaching media in language context is not too essential (Hart, 2001) is gradually changed to recent practice. A lot of research findings proved that media contribute to asisst the students' progress in language learning (Mayora, 2009; Guo, 2013; Dvorghets \& Shaturnaya, 2015). Applying Internet based media in language learning is considered significant (Morgan, 2009; 
Megawati \& Sultoni, 2017; Zhuravleva, de Bot, \& Hilton, 2016). Equipping the students with the information for how to create media online is one of the ways to grab the students' attention. Colourful images, interactive moving motion, and clear intonation of native speakers' voice support the contextual instruction. Combining non digital and digital media is the best option for balanced portion in delivering knowledge. Both teachers and students have to be familiar with the right function of online media in helping to develop the language competence.

Micro Teaching in this context is focused on an independent compulsory subject in the education program to prepare the teacher in facing real school experience. It generally comprises two credits in one semester, which emphasizes peer teaching performance. Collaborating theories and mini practicum will build preservice teachers confidence and teaching skill gradually. In some context micro teaching is integrated in the teaching method course. A study on Micro teaching itself has been conducted and found positive and negative effect to the students' competence and experience (Undiyaundeye \& Inakwu, 2012; Bak, 2014).

However, correlating the teaching practicum experience with the existence of previous courses, namely Teaching Media and Micro Teaching, has been found to be limited (Utomo, 2012). It is considered significant to get the information to know to what extent they make a use of their knowledge and skill in the real school. Therefore, through this study, the researchers explored the washback effect of the two courses provided by faculty to prepare the pre-service readiness in teaching during their practicum.

\section{Methodology}

Qualitative research was utilized for this investigation through distributing online questionnaires to twenty nine participants. The dominant participants were female pre-service teachers. Most of them have no teaching experience before doing teaching practicum. They claimed that the teaching practicum program was the first time they implemented and developed what they got from university courses. The data collection was carried out a week after the prospective teachers finished their teaching practicum on their even semester, academic year 2017-2018. The open-ended survey questions are described as follow:

1. What kind of teaching media did you apply during teaching practicum program?

2. What media are effective for your teaching? Why?

3. Can you share your students' general competence in using technology based learning?

4. Can you share details about the teachers' general competence in using technology?

5. Describe briefly the availability of Internet access in the school area

6. Reflecting to the teaching performance during Micro Teaching course, can you give me your opinion on the things that you find similar, different, even new in the school? 
After the responses of questionnaires returned, the researchers started analysing the relevant information obtained from the subjects. To get deeper data, the participants had been asked to submit their teaching practice experience journal to be analyzed in term of their memorable event during carrying out their first English teaching in the partner schools. In their writing, the student teachers were allowed to give email addresses and insert any data that could support their story such as pictures, screen shoot of online communication during teaching practicum, document of lesson plan, and so forth. In order to get relevant information, data reduction was done manually followed by coding. The result of coding was then converted into table to get clear visual category to answer the research focus. From the analysis, three themes were finally developed.

\section{Findings and Discussion}

\subsection{Types of Media used in Teaching Practicum}

The data indicated that only some of media presented in the Teaching Media course were used. In the course, they were introduced to use offline and online media. At that time, the class was designed to equip students' skill with theories of general kinds of media and the ASSURE model in the first and second meetings followed by individual, pair, or group projects for 7 types. The media processed for the projects included graphs, diagram, charts; audio recordings; stick puppets; big book; pop-up book; songs; toolsforeducators application form http://www.toolforeducators.com/; mysimpleshow application from www.mysimpleshow.com. The result of the questionnaire was coded and the media implemented for the practicum was classified based on the number of users in Table 1.

Table 1. Media used in English Teaching Practicum

\begin{tabular}{cc}
\hline Media & Number of student teacher \\
\hline Stick puppet & 4 \\
Big book & 2 \\
Flash card & 5 \\
Power point & 8 \\
Video & 6 \\
Poster & 1 \\
Card & 1 \\
Song & 1 \\
Picture series & 1 \\
\hline
\end{tabular}

From the result, the media in the forms of graph, diagram, chart, recordings, tools for educators, and mysimpleshow were not implemented. In other words, the nine media mentioned in Table 1 were considered effective to assist the students' learning. Power point was most frequently used as the material explainer. It indicates that the student teachers were skillful to create slides for their instruction. Besides, the school students already get accustomed to learning with Power Point. The availability of LCD projectors in most schools could accommodate the use of explainer in addition to writing on the white board. 
Flash cards can be designed and prepared easily for learning vocabulary items when teaching secondary school students, particularly junior high school level. In addition to buying the available flashcards in book stores, selecting suitable pictures and printing them in medium was the strategy to prepare English class activities with flash cards. The self-made teachers' flash cards were mostly selected by student teachers to provide instructional media for their language learners. Furthermore, previous studies have proved that the use of flash cards is effective for teaching junior high school students, not only for elementary school students (Auliya, 2016; Apriliani, 2016). Thus, their knowledge of media implementation got from reading journal article activities also encouraged them to try flash cards in teaching English during teaching practicum.

Stick puppets were the next interesting media to use because they were easy to create and the students could construct the puppets in the classroom before they apply them for English lesson. In the teaching practicum, the school students were instructed to bring tools such as ice cream stick, glue, and pictures to create their stick puppets. They showed good cooperation and enthusiasm for realizing the activities, especially doing role play in performing pair dialogue. In line with this, Raudha Siregar \& Tavriyanti (2014) and Fauza (2018) give empirical data that using puppets can improve the language learners' speaking skill as well as learning motivation.

Almost similar context with previous discussion, big books, media commonly used in elementary school, was tried to be implemented in junior high school students. Exploring language class with Big Book was done by two student teachers. They used their own creativity to develop the Big Book by identifying the learning objectives they wanted to achieve. They also have considered the possible positive result before bringing big book to the class. Matching the materials and media with the learning objectives are significant to do to make the lesson more meaningful. The practice indicates that as long as the teachers can read the classroom conditions that there is an opportunity to attract students' attention to the teacher's explanation through media, any media including big book can be used as variation for teaching.

Regardless the use of some media that are usually used in elementary school such as flash cards, puppets, and big book, in certain schools those are still relevant to be implemented at junior high school level. The students' response toward the media showed positive attitude which indicates that they needed variation in classroom activities. Creativity in designing and creating media as well as interaction in explaining the content of materials through the media are the key points.

In contrast, poster, card, song, and picture series were not used a lot. Focusing on the song; at that time the curriculum did not mention song as the competence to master in the lesson. In addition, student teachers did not get enough facilities to play the audio or music in the classroom and they did not get access to invite the students to learn in the language laboratory. They had to bring their own 
loud speaker for giving listening activities to the students if they wanted to do it. In this case, teacher candidates found that the listening skills for junior and senior high school was not the focus of lesson.

It was then investigated that the online based media were not mostly used in the school because of some factors. The first is technical issue or poor internet connection. The access of the Internet determines the quality of virtual activities, but not all schools could provide it. Second, the motivation of using online media. For some institutions, teachers found offline media effective for learning. Thus, they were reluctant to change into online although the school provided internet access. The third factor is the students' low skill in operating online tools. To implement online based learning, the students need to understand the way how to operate it. Consequently, this asked them to learn intensively with their gadgets. In contrast, not all of them were not facilitated by the family and the school.

For the teachers who had implemented online media, YouTube video was found to be the favourable option. The easy access to download video from YouTube gives student teachers more opportunities to provide various materials and visual media. A study supported the feature of video is conducted by Pan et al. (2012). He found that the use of videos is helpful as a scaffolding tool before, during and after lectures.

\subsection{Contrasting Micro Teaching Class and Teaching Practicum Subject}

For analyzing the data dealing with Micro Teaching class, the researchers focus on the differences in the real school to highlight whether it gives benefits or potential problems for the pre-service teachers' teaching practice. The following section is the data taken from the selected answers.

\section{Differrence\#1}

I cannot apply my "previous" lesson plan because the teacher has her own style and rule. Also, I got problem while consult with the institutional advisor related to method, model, technique, assessment according to Curriculum 2013.

\section{Difference\#2}

We just teach our friends in Micro Teaching, and we know the characteristic of our friends, but in real school, we do not know the characteristic of the students.

\section{Difference\#3}

The difference is the challenging atmosphere in the school.

\section{Difference\#4}

It is difficult to gain the students' attention, the activity learning did not match with lesson plan. We need to be more patient to explain the material.

\section{Difference\#5}

One of the differences, I am more nervous when I teach in the class compared with teaching with my own friends. I found many different characteristic of students, so I was little difficult to manage classroom. 


\section{Difference\#6}

They are many characteristics of students.

\section{Difference\#7}

When we teach in school we have to face the real students who have different abilities.

\section{Difference\#8}

To make a lesson plan especially to know how many meetings in one $K D$, we must make Prota and Promes. I did not get it when I' $m$ in micro teaching class

\section{Difference\#9}

It's more difficult to manage the classroom when students were noisy and I felt more nervous when I start to teach them.

\section{Difference\#10}

They have their own curriculum and their own book. And they have additional class such as speaking and listening class after the regular class.

\section{Difference\#11}

There were many differences when I taught in SMKM and in micro teaching, namely audience, technique and situation. I learn how to manage student that mostly boy, how to make effective class, and how to explain my material to them.

The diversity of students' ideas in answering the questionnaire concerning the difference happening in teaching practice explains three main points. Lesson planning was the primary concern. It deals with lesson plan construction, curriculum, prota or yearly program, promes or semester program. The second is the issue of classroom management, particularly handling students' different characteristics, abilities, and personalities (confidence). Those two elements are actually interrelated with each other in some cases. For example, when the preservice teachers were in a situation where the lesson plan could not run well, it influenced their ability on how to continue the class for about eighty or ninety minutes. Brown (2007) suggests that teachers should have a back-up plan for facing this kind of situation. The existence of another planning becomes the alternative to keep continuing the teaching and learning activities.

When dealing with classroom management and personalities, it can be hard to manage the class, especially for the classes who have students with very active personalities. It also becomes worse if the prospective teachers do not have high confidence in facing the situation. As a result, it can be stressful for them (Coşkun, 2013). Contrastively, if the pre-service teachers are not too nervous and feel like they teach their brothers or sisters, the class will not be too uncontrolled. Accordingly, building character to be a caring teacher need to be strengthened in order that the student teachers are always ready with surprising condition in their classes (Lumpkin, 2007; Webb \& Blond, 1995). In line with this, the readiness is also associated with the level of self-efficacy and teacher identity. When they got more positive experiences, the more they believe that they are able to teach and the more they strengthen their teacher identity. 


\subsection{What does teaching practicum journal say?}

Gathering essays for confirming the findings in questionnaires is a complex process. To simplify the idea, the researchers used coding to discover the relevant points to answer the research problems. The interpretation of the data is summarized in Table 2. Letter E is abbreviation for pre-service teachers' essay followed by number. Next, determining relevant statements through selecting words, phrase, and sentences which expressed their impressions or feelings. The last column summarized the experience and there was additional information for specific classification.

Table 2. The Summary of Teaching Practicum Journal

\begin{tabular}{|c|c|c|}
\hline $\begin{array}{c}\text { Essay } \\
\text { Number }\end{array}$ & Relevant Statement & Coding \\
\hline E\#1 & $\begin{array}{l}\text { - Stressful } \\
\text { - Need louder voice } \\
\text { - Students keep passive }\end{array}$ & $\begin{array}{l}\text { Frightening } \\
\text { Affective }\end{array}$ \\
\hline E\#2 & - Can't stand with noisy students & $\begin{array}{l}\text { Frightening } \\
\text { Method }\end{array}$ \\
\hline E\#3 & $\begin{array}{l}\text { - Giving up in facing students rejecting to use } \\
\text { English } \\
\text { - The media prepared do not get positive response } \\
\text { - Need to have more games for back-up plan }\end{array}$ & $\begin{array}{l}\text { Frightening } \\
\text { English use } \\
\text { Method }\end{array}$ \\
\hline E\#4 & No preparation, no attention & $\begin{array}{l}\text { Frightening } \\
\text { Lesson plan }\end{array}$ \\
\hline E\#5 & $\begin{array}{l}\text { - Learning to be more patient to face smart students } \\
\text { who acted unrespectedly } \\
\text {-Using English to show English teacher power }\end{array}$ & $\begin{array}{l}\text { Challenging } \\
\text { Affective }\end{array}$ \\
\hline E\#6 & $\begin{array}{l}\text {-Promoting teamwork through jigsaw method with } \\
\text { its strengths and weaknesses. }\end{array}$ & $\begin{array}{l}\text { Challenging } \\
\text { Method }\end{array}$ \\
\hline E\#7 & Trying to be a facilitator in the class & $\begin{array}{l}\text { Challenging } \\
\text { Role }\end{array}$ \\
\hline E\#8 & $\begin{array}{l}\text { Enjoying managing varied learners, namely } \\
\text { student with special need, low learners, } \\
\text { hyperactive learner, and hippoactive learner }\end{array}$ & $\begin{array}{l}\text { Challenging } \\
\text { Method }\end{array}$ \\
\hline E\#9 & $\begin{array}{l}\text { Feeling special because the students miss her } \\
\text { coming to teach the class } \\
\text { Games and rewards are necessary to prepare }\end{array}$ & $\begin{array}{l}\text { Challenging } \\
\text { Method }\end{array}$ \\
\hline E\#10 & $\begin{array}{l}\text { - Using video to minimize the noise } \\
\text { - Claimed herself as a helpful teacher. }\end{array}$ & $\begin{array}{l}\text { Challenging } \\
\text { Method }\end{array}$ \\
\hline E\#11 & $\begin{array}{l}\text { - Applying technology-based learning strategy } \\
\text { - Using song lyric flashcards } \\
\text { - Using online based test to avoid cheating }\end{array}$ & $\begin{array}{l}\text { Challenging } \\
\text { Method }\end{array}$ \\
\hline E\#12 & $\begin{array}{l}\text { - Seeing active contribution from the students in } \\
\text { the class. } \\
\text { - Trying to be an interesting teacher to create joy in } \\
\text { the class. }\end{array}$ & $\begin{array}{l}\text { Challenging } \\
\text { Method }\end{array}$ \\
\hline E\#13 & $\begin{array}{l}\text { - Has chemistry with the students } \\
\text { - Getting many advantages from the internship } \\
\text { program }\end{array}$ & $\begin{array}{l}\text { Challenging } \\
\text { Affective }\end{array}$ \\
\hline
\end{tabular}




\begin{tabular}{|c|c|c|}
\hline $\begin{array}{c}\text { Essay } \\
\text { Number }\end{array}$ & Relevant Statement & Coding \\
\hline E\#14 & $\begin{array}{l}\text { - Can teach a class with a disabled student } \\
\text { - Can handle trouble makers with her teaching } \\
\text { strategy }\end{array}$ & $\begin{array}{l}\text { Challenging } \\
\text { Media }\end{array}$ \\
\hline E\#15 & $\begin{array}{l}\text { - The students were cooperative } \\
\text { - Can be a facilitator for the students }\end{array}$ & $\begin{array}{l}\text { Challenging } \\
\text { Media }\end{array}$ \\
\hline E\#16 & $\begin{array}{l}\text { - Large class did not make him nervous. } \\
\text { - The students were enthusiastic } \\
\text { - Using flash card } \\
\text { - Using group work } \\
\text { - Motivate students with work honestly }\end{array}$ & $\begin{array}{l}\text { Challenging } \\
\text { Method \& Media }\end{array}$ \\
\hline E\#17 & $\begin{array}{l}\text { - Video and flash card can attract students' } \\
\text { positive impression }\end{array}$ & $\begin{array}{l}\text { Challenging } \\
\text { Media }\end{array}$ \\
\hline E\#18 & $\begin{array}{l}\text { - Implementing the idea of a teacher is a friend. } \\
\text { - Teaching student with special need }\end{array}$ & $\begin{array}{l}\text { Challenging } \\
\text { Role } \\
\text { Method }\end{array}$ \\
\hline E\#19 & Trying to enjoy and smile & $\begin{array}{l}\text { Challenging } \\
\text { Affective }\end{array}$ \\
\hline E\#20 & $\begin{array}{l}\text { - Teaching male students in a class in vocational } \\
\text { high school gives different situation } \\
\text { - Preparing stationary for the students } \\
\text { - Implementing group work }\end{array}$ & $\begin{array}{l}\text { Challenging } \\
\text { Method } \\
\text { Affective }\end{array}$ \\
\hline E\#21 & - Stimulating the students to be more active & $\begin{array}{l}\text { Challenging } \\
\text { Method }\end{array}$ \\
\hline E\#22 & $\begin{array}{l}\text { - Teaching only male students in the class is the } \\
\text { challenge }\end{array}$ & $\begin{array}{l}\text { Challenging } \\
\text { Method }\end{array}$ \\
\hline E\#23 & $\begin{array}{l}\text { - Becoming closer with students } \\
\text { - Encouraging students active participation } \\
\text { through point and reward } \\
\text { - Felling energetic to teach the students }\end{array}$ & $\begin{array}{l}\text { Challenging } \\
\text { Role } \\
\text { Affective }\end{array}$ \\
\hline E\#24 & $\begin{array}{l}\text { - Encouraging student's confidence through group } \\
\text { discussion } \\
\text { - Overcoming crowded situation through standing } \\
\text { up and gazing the students. }\end{array}$ & $\begin{array}{l}\text { Challenging } \\
\text { Method }\end{array}$ \\
\hline E\#25 & $\begin{array}{l}\text { - Learning a lot of things from problems she found } \\
\text { - Using innovative media and games } \\
\text { - Approaching students like friend } \\
\text { - Inserting character education when teaching the } \\
\text { class }\end{array}$ & $\begin{array}{l}\text { Challenging } \\
\text { Method } \\
\text { Role as friend }\end{array}$ \\
\hline E\#26 & $\begin{array}{l}\text { - Making an agreement before class } \\
\text { - Giving rewards to create fun learning }\end{array}$ & $\begin{array}{l}\text { Challenging } \\
\text { Method } \\
\text { Affective }\end{array}$ \\
\hline E\#27 & $\begin{array}{l}\text { - Using penalty } \\
\text { - Using classroom chat }\end{array}$ & $\begin{array}{l}\text { Challenging } \\
\text { Method }\end{array}$ \\
\hline E\#28 & - Animated video helps a lot & $\begin{array}{l}\text { Challenging } \\
\text { Media }\end{array}$ \\
\hline E\#29 & - YouTube video is effective & $\begin{array}{l}\text { Challenging } \\
\text { Media }\end{array}$ \\
\hline
\end{tabular}


The information gathered from the teaching practicum essays accumulate the general impression of the participants' experience. After tracking pivotal points in clarifying the data, it is obtained that the unforgettable activities conducted by student teachers in the school focused on English use in the class, teacher's voice, method, media, role as facilitator and friend, affective factors. The method was elaborated in two concerns, namely method of language teaching and method of classroom management. For the first until fourth responses that represented frightening impression, it is believed that such events were unexpected to happen, and of course they felt uncomfortable when facing it. Those negative experiences are also parts of critical incidents which contribute to the success or failure in constructing one's teacher identity (Farrell, 2008).

In language teaching method analysis, the data showed that group discussion was found effective for stimulating the students' activeness. The more the students engage in discussion, the more language they would produce. To make it more meaningful, trainee teacher's control is needed to encourage the use of English when expressing their opinion. In methods of classroom management, some students admitted the importance of agreement in the course (Thornberg, 2008; Boostrom, 1991). Ideally, it should be set before the class, and teachers should give rewards for the students' contribution (Marinak \& Gambrell, 2008). The agreement can build students' responsibility to obey the rule, and it will make them more disciplined if the consequences are done consistently.

Accordingly, the category of response can be divided into two, challenging and frightening. Frightening means from the whole activities during the program the pre-service teachers tend to show their experience not in positive feelings. All statements indicated that the event made them give up to repeat the same things, the event creates the mindset not to be an English teacher. In contrast, challenging moment explains that the prospective teachers found problems at first and could pass the following meetings with a lot of variation in teaching and in managing classroom. Some of them clearly state that the role of teaching a media course shows positive contribution in attracting students' attention (Kuppens, 2010; King, 2002).

\section{Conclusion}

Briefly, this study gives insight that investigating English as Foreign Language (EFL) pre-service teachers in transferring their language knowledge and developing teaching skill is significant for evaluating the effective components inserted in supporting courses provided by study program. The need of giving exposure from reading the research results also play an important role to strengthen the prospective teachers' knowledge in selecting and implementing certain media for English instruction.

Each experience in this study has shown unique results to decide whether or not it was frightening or challenging, or even both in the same time. To answer this, a lot of factors need to be integrated to achieve comprehensible perception. In fact, the contribution of the Micro Teaching class and Teaching Media course in 
the previous semester before conducting teaching practice gave the student teachers benefits in generating their ideas for facing the real school situation. However, in some cases it seems that there was an inadequate concept or skill the students cannot follow well that affect to their performance. In this respect, teaching practice gives faculty members feedback how the process runs in the field.

Further, it implicitly suggests evaluating the existing policy for the program so that improvement to the related parties can be coordinated and distributed as expected; mainly to train quality English teachers in the future. It can be suggested for future researchers who are interested in the same focus to emphasize specific area to be analyzed in term of the teaching practicum called $P L P$ program as the current formation of the teaching practice in Indonesian curriculum context.

\section{References}

Adnan, M. (2017). Perceptions of senior-year ELT students for flipped classroom: a materials development course. Computer Assisted Language Learning, 30(3-4), 204-222. https:/ / doi.org/10.1080/09588221.2017.1301958Agustiani, M. (2016, September). Teachers'demotivation in English language teaching: causes and solutions. In Sriwijaya University Learning and Education International Conference (Vol. 2, No. 1, Pp. 672-682).

Apriliani, I. (2016). A study on flash cards in teaching vocabulary for seventh grade students at MTS Negeri II Surakarta in the academic year of 2015/2016. English Education Study Program, the Islamic Education and Teacher Training Faculty, The State Islamic Institute of Surakarta. Retrieved from http://eprints.iainsurakarta.ac.id/698/1/Ika Apriliani.pdf

Auliya, Z. (2016). Improving student's vocabulary mastery through flashcards at the seventh grade students of SMP PGRI Karangampel. English Language Teaching Department, Tarbiyah and Teacher Training Faculty, Syekh Nurjati State Islamic Institute Cirebon. Retrieved from http://repository.syekhnurjati.ac.id/2735/1/zakki auliya-min.pdf

Bak, S. (2014). The effect of microteaching on the teaching skills of pre- service science teachers. Journal of Baltic Science Education, 13(6), 789-801.

Boostrom, R. (1991). The nature and functions of classroom rules. Curriculum Inquiry, 21(2), 193-216. https:/ / doi.org/10.1080/03626784.1991.11075363

Brown, H. D. (2007). Teaching by principles : an interactive approach to language pedagogy. Pearson Education.

Coşkun, A. (2013). Stress in English language teaching practicum: the views of all stakeholders. Hacettepe Üniversitesi Ë̆itim Fakültesi Dergisi, 28(28-3), 97-110.

Curran, M. E. (2003). Linguistic diversity and classroom management. Theory Into Practice, 42(4), 334-340. https://doi.org/10.1207/s15430421tip4204_11

Dvorghets, O. S., \& Shaturnaya, Y. A. (2015). Developing students' media literacy in the English language teaching context. Procedia - Social and Behavioral Sciences, 200, 192-198. https://doi.org/10.1016/j.sbspro.2015.08.051

Goodwin, A. L., \& Kosnik, C. (2013). Quality teacher educators = quality teachers? Conceptualizing essential domains of knowledge for those who teach teachers. Teacher Development, 17(3), 334-346. https:// doi.org/10.1080/13664530.2013.813766

Guo, R. X. (2013). The use of video recordings as an effective tool to Improve 
Presentation Skills. Polyglossia, 24, 92-101.

Fauza, H. (2018). Improving students' speaking skill and motivation by using hand puppets show media. English Education Journal, 9(2), 216-228. Retrieved from http://jurnal.unsyiah.ac.id/EEJ/article/view/11529

Farrell, T. S. C. (2008). Critical incidents in ELT initial teacher training. ELT Journal, 62(1), 3-10. https://doi.org/10.1093/elt/ccm072

Hart, A. (2001). Awkward practice: Teaching media in English. Changing English, 8(1), 65-81. https://doi.org/10.1080/13586840125055

King, J. (2002). Using DVD Feature films in the EFL classroom. Computer Assisted Language Learning, 15(5), 509-523. https:/ / doi.org/10.1076/call.15.5.509.13468

Kuppens, A. H. (2010). Incidental foreign language acquisition from media exposure. Learning, Media and Technology, 35(1), 65-85.

https://doi.org/10.1080/17439880903561876

Ko, M.-H. (2017). Learner perspectives regarding device type in technology-assisted language learning. Computer Assisted Language Learning, 30(8), 844-863. https://doi.org/10.1080/09588221.2017.1367310Lumpkin, A. (2007). Caring teachers the key to student learning. Kappa Delta Pi Record, 43(4), 158-160. https://doi.org/10.1080/00228958.2007.10516474

Marinak, B. A., \& Gambrell, L. B. (2008). Intrinsic motivation and Rewards: What sustains young children's engagement with text? Literacy Research and Instruction, 47(1), 9-26. https://doi.org/10.1080/19388070701749546

Mayora, C. A. (2009). Using youtube to encourage authentic writing in EFL classrooms, 1-12. TESL Reporter, 42(1), 1-12.

Megawati, F., \& Sultoni, S. (2017). Android based educational game in Indonesian TEYL. In Android based Educational Game in Indonesian TEYL (pp. 662-668). Surabaya: UNIPA. https:// doi.org/10.6084/M9.FIGSHARE.4559218.V3

Morgan, B. (2009). Revitalising the essay in an English for academic purposes course: critical engagement, multiliteracies and the internet. International Journal of Bilingual Education and Bilingualism, 12(3), 309-324. https://doi.org/10.1080/13670050802153350

Pan, G., Sen, S., Starrett, D. A., Bonk, C. J., Rodgers, M. L., Tikoo, M., \& Powell, D. V. (2012). Instructor-made videos as a scaffolding tool. Journal of Online Learning and Teaching, 8(4), 298.

Pavić, N. (2014). EFL teacher motivation. University of Zagreb.

Raudha Siregar, N., \& Tavriyanti, L. (2014). Teaching speaking by using puppet play for junior high school students. Retrieved from

http://www.ejurnal.bunghatta.ac.id/index.php?journal=JFKIP\&page=article\&o $\mathrm{p}=$ viewFile\&path []$=3622 \&$ path []$=3107$

Riesky, R. (2013). How English student teachers deal with teaching difficulties in their teaching practicum. Indonesian Journal of Applied Linguistics, 2(2), 250. https:// doi.org/10.17509/ijal.v2i2.169

Selwyn, N., \& Husen, O. (2010). The educational benefits of technological competence: an investigation of students' perceptions. Evaluation \& Research in Education, 23(2), 137-141. https:// doi.org/10.1080/09500790.2010.483515

Thornberg, R. (2008). A categorisation of school rules. Educational Studies, 34(1), 25-33. https://doi.org/10.1080/03055690701785244

Undiyaundeye, F., \& Inakwu, A. A. (2012). Micro-Teaching Experiences in a Pre-Service Early Childhood Education Programme. https:// doi.org/10.20533/ijtie.2047.0533.2012.0014

Utomo, S. W. (2012). Pengaruh prestasi belajar perencanaan pengajaran dan micro 
teaching terhadap praktik pengalaman lapangan mahasiswa pendidikan akuntansi IKIP PGRI Madiun. Assets: Jurnal Akuntansi Dan Pendidikan, 1(1), 5665. Retrieved from http://e-

journal.unipma.ac.id/index.php/assets/article/view/544

Webb, K., \& Blond, J. (1995). Teacher knowledge: The relationship between caring and knowing. Teaching and Teacher Education, 11(6), 611-625. https:// doi.org/10.1016/0742-051X(95)00017-E

Zhuravleva, A., de Bot, K., \& Hilton, N. H. (2016). Using social media to measure language use. Journal of Multilingual and Multicultural Development, 37(6), 601614. https://doi.org/10.1080/01434632.2015.1111894 